\title{
Taxonomy and distribution of aquatic and semiaquatic Heteroptera (Insecta) from Cuba
}

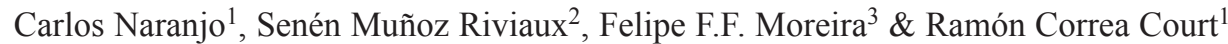

1. Departamento de Biología, Faculdad de Ciencias Naturales de la Universidad de Oriente, Santiago de Cuba, Patricio Lumumba s/n esq. Ave. de las Américas. C. Postal 90500, Cuba; naranjo@cnt.uo.edu.cu

2. Departamento de Cuencas Hidrográficas (CATEDES), Ignacio Agramante $\mathrm{N}^{\circ} 818$ e/n Aguilera y Prado, CP: 95100, Guantánamo, Cuba; senen@catedes.gtmo.inf.cu

3. Universidade Federal do Rio de Janeiro, Instituto de Biologia, Departamento de Zoologia, Laboratório de Entomologia. Avenida Brigadeiro Trompowski, s/n, bloco A, sala 107, Ilha do Fundão, Rio de Janeiro, RJ, Brazil. CEP 21941-971, C. Postal 68044; felipento@hotmail.com

\section{Received 19-VII-2009. C Corrected 08-II-2010. Accepted 05-III-2010.}

\begin{abstract}
Heteroptera is a worldwide distributed group of insects inhabiting both terrestrial and aquatic habitats and has an important ecological role. A survey of aquatic and semiaquatic Heteroptera from Cuba is provided based on literature reports and field collections. General data on species geographical distribution are given, along with altitude and collection season. Representatives of 86 species and morphospecies of the infraorders Dipsocoromorpha, Leptopodomorpha, Gerromorpha and Nepomorpha are listed, distributed in 35 genera and 16 families were found. Based on distributional data, a preference for habitats of stagnant water or slow current and lower altitudes is inferred. Fifteen species are distributed throughout the entire island. A higher species diversity was found in the Eastern sector, with 53 species (61.63\%), 16 of which (18.60\%) are confined to this area. The strongest biological similarity was found between Eastern and Western sectors (25\%), and the weakest between Western and Central sectors (14\%). Rev. Biol. Trop. 58 (3): 897-907. Epub 2010 September 01.
\end{abstract}

Key words: biodiversity, biogeography, check list, Neotropical Region, water bugs.

The suborder Heteroptera comprises a very interesting group of insects with a worldwide distribution. Most of the species are terrestrial, but many are found in stagnant or running freshwater habitats, estuaries, and even in open ocean waters (Nieser \& Melo 1997, Andersen 1982). Generally, the aquatic and semiaquatic Heteroptera are predators with an intermediate stage in the food chains of their respective communities; some species may have economic importance as predators of mosquito larvae and adults, or as food for fish (Jenkins 1964, Menke 1979).

Most species of the aquatic and semiaquatic Heteroptera belong to the infraorders Leptopodomorpha, Gerromorpha and Nepomorpha, with the last two encompassing approximately $92 \%$ of the aquatic bugs diversity (Polhemus \& Polhemus 2008). According to Polhemus \& Polhemus (2007), since the 1970 's, major taxonomic activity concerning Neotropical water bugs is represented by works on Suriname, adjacent Northern South America, the Caribbean and Mexico, with the exception of the monograph of the genus Rhagovelia Mayr, 1865 of the Western Hemisphere (Polhemus 1997).

As for the Cuban island, there is a great gap of knowledge concerning this fauna, since only three significant taxonomic surveys of aquatic Heteroptera have been published up to date (Guérin-Méneville 1857, Alayo 1967, 1971, 1974, Nieser 1973, 1977). In this contribution, we present a review of the studies on 
aquatic and semiaquatic Heteroptera reported from Cuba, an updated list of species, and biogeographical and distributional data.

\section{MATERIALS AND METHODS}

For species survey and information on their geographic distribution, a thorough bibliographic review, of published studies and recent monographs regarding aquatic insects from Universidade de Oriente, was undertaken. Also, specimens from different collections, made by researchers from the Departamento de Biología de la Universidade de Oriente throughout the country, were examined. Not all surveyed species were included in biogeographical and distributional discussions, because some of them presented incomplete locality or habitat data.

Tables were produced linking each species to biogeographical, habitat, season, and altitude data. For biogeographic distribution analysis, Samek (1973) regionalization criterion and Tsechanovsky's Index of Biological Similarity (BSI) (Feinsinger 2004) were applied. For habitat preference evaluation, habitats were divided into areas of flowing or stagnant water, the latter including river or stream pools, as well as ponds of any kind. For inferring altitudinal distribution, four groups were defined: species found up to $60 \mathrm{~m}$ asl (A), up to $200 \mathrm{~m}$ asl (B), up to $600 \mathrm{~m}$ asl (C), and up to $750 \mathrm{~m}$ asl (D). Seasonal distribution evaluation was based on available data from 46 species, which were grouped according to season (dry or rainy) of collection. Altitudinal distribution of Cuban aquatic bugs was inferred from data available for 39 species.

\section{RESULTS}

Brief history of Cuban aquatic and semiaquatic Heteroptera: In the 19th century, the classic work of Guérin-Méneville (1857) listed 14 species (not including synonyms and misidentified species) of aquatic and semiaquatic Heteroptera from Cuba, belonging to the families Saldidae, Gerridae, Hydrometridae, Veliidae, Belostomatidae, Corixidae, Naucoridae, Nepidae, and Notonectidae.

In Kirkaldy \& Torre-Bueno (1909), excluding synonyms and errors of identification and distribution, 25 species were mentioned for Cuba, including records for Mesoveliidae and Pleidae. It is important to mention that records for Neoplea striola (Fieber, 1844) from Cuba cited by Kirkaldy \& Torre-Bueno (1909) and previous works, actually belong to Paraplea puella (Barber, 1923). In addition, Gelastocoris oculatus oculatus (Fabricius, 1798) and G. o. variegatus (Guérin-Méneville, 1844), treated as different species instead of subspecies, were cited by various authors for different localities from Insular Central America, but Kirkaldy \& Torre-Bueno (1909) regarded those records as doubtful.

After the above cited works, isolated descriptions of species and studies on specific families or genera were made (Martin 1928, Anderson, 1932, Hungerford 1933, Hungerford \& Evans 1934, Drake 1938, Kuitert 1942, Drake \& Harris 1942, 1943, Hungerford 1948, Drake 1952, Truxal 1953, Hungerford 1954, Drake \& De Carlo 1953, Drake \& Hussey 1955, Lauck 1959, Menke 1963, Drake \& Van Doesburg 1966). Those studies added 27 species to Cuban fauna, including records for Ochteridae and Hebridae, and ensuring the occurrence of Gelastocoridae.

However, the first taxonomic study dealing specifically with aquatic and semiaquatic Heteroptera from Cuba was published only by Alayo (1967), who listed and keyed 14 families, 30 genera and 63 species. Additions and emendations to this study were published by Alayo (1971), and an updated version in Alayo (1974), with 14 families, 32 genera and 68 species. New country records for 10 species were presented in Alayo's papers, including two Saldidae, three Gerridae, two Hebridae, one Mesoveliidae and two Veliidae.

Alayo (1974) recorded an undetermined species of Laccocoris Stål, 1856 from Cuba. However, the occurrence of the genus in America is highly questionable, and thus the record 
should not be considered valid. Considering the doubtful presence of Laccocoris, the synonymy between Trochopus Carpenter, 1898 and Rhagovelia proposed by Polhemus (1997), the revalidation of Neogerris Matsumura, 1913 by Andersen (1975), and the newly described genera Platyvelia Polhemus \& Polhemus, 1993 and Steinovelia Polhemus \& Polhemus, 1993, the number of currently valid genera in Alayo (1974) remains 32.

Nieser (1973, 1977) enriched Alayo's list by adding one family (Dipsocoridae), three genera (Cryptostemma Herrich-Schäffer, 1835; Eurygerris Hungerford \& Matsuda, 1958; and Corisella Lundblad, 1928), and six species. Since then, just a few contributions to the knowledge of aquatic Heteroptera of Cuba were made, and only Trepobates carri Kittle, 1982, Hermatobates breddini Herring, 1965 and Rhagovelia cubana Polhemus, 1997 have been newly recorded from the country (Polhemus \& Herring 1979, Kittle 1982, Polhemus 1997).

Taxonomy: An updated list of Cuban aquatic and semiaquatic Heteroptera was generated, with 86 species and morphospecies, 35 genera and 16 families. Eurygerris dominicus (Drake \& Maldonado-Capriles 1956), known only from Dominican Republic up to the date, is recorded from Cuba for the first time.

Ten morphospecies were found, representing either possibly undescribed taxa or new records to Cuban fauna: (1) Saldidae Gen. sp 1, recorded from Río Guantánamo, Guantánamo (Álvarez 2007); (2) Saldidae Gen. sp 2, from Río Cacoyoguín, Holguín (Hernández \& Bauta 2003); (3) Limnogonus sp., from Río Gibara, Holguín (Hernández \& Bauta 2003); (4) Metrobates sp., from Río Mayarí, Holguín (Aldana \& Fonseca 2001); (5) Rheumatobates sp. and (6) Buenoa sp., from Río Máximo, Camagüey (Bello 2004); (7) Trepobates sp., from Río Cacoyoguín, Holguín (Hernández \& Bauta 2003); (8) Hydrometra sp. from Hoyo de Fania, Pinar del Río (Nieser 1977); and (9) Microvelia sp. and (10) Trichocorixa sp., from Río Cauto, Granma (Hernández \& Cala 2003).
Updates on those species will be published in forthcoming papers.

Besides Laccocoris sp., records of four other species cited by Alayo (1974) were not taken in consideration in the elaboration of the checklist: (1) Limnogonus hyalinus (Fabricius 1803), as Alayo affirmed that he had just one unlabeled specimen doubtfully belonging to this species and no others records from Cuba were found; (2) Microvelia capitata Guérin-Méneville, 1857, based in an inaccurate description and unknown type-series, which was considered a probable junior-synonym of M. pulchella Westwood, 1834 by Drake \& Hussey (1955); (3) Buenoa femoralis (Fieber, 1851) and (4) Lethocerus annulipes (HerrichSchäffer 1846), included among Cuban species by Alayo based only in records from nearby Puerto Rico and Hispaniola (Menke 1963), but that does not occur on Cuba (Perez-Goodwyn 2006).

Some other mistaken records for the aquatic and semiaquatic Heteroptera from Cuba were found in literature. The species Ochterus perbosci (Guérin-Méneville, 1843) was cited from Cuba by Champion (1901), based on Uhler (1893, 1894). However, the species recorded in both Uhler's articles were collected in St. Vincent and Grenada, but not in Cuba.

Several erroneous records were due to nomenclatural problems involving Central American Nepomorpha Notonecta indica Linnaeus, 1771 was mistakenly cited in literature as N. americana Fabricius, 1775 and N. undulata Say, 1832 (Hungerford 1933, Alayo 1974). Trichocorixa louisianae Jackzewski, 1931 was mistakenly identified as $T$. reticulata (GuérinMéneville, 1857) by several authors, but is not a synonym of the latter species. The actual $T$. reticulata is a senior-synonym of $T$. wallengreni (Stål, 1859), T. blackburni (White, 1877) and T. mariae (Champion, 1901).

Belostoma apache cubaensis Mayr, 1871, also cited by Alayo $(1967,1974)$ and DelerHernández et al. (2007), is a junior-synonym of B. minor (Palisot de Beauvois, 1805). Belostoma boscii (Lepeletier \& Serville, 1863), cited from Cuba by Alayo and other authors, is a 
nomen dubium, and thus not considered here. Both B. anurum (Herrich-Schäffer, 1848) and B. elongatum Montandon, 1908 were recorded from the island, but are in fact restricted to central and Southern South America (Lauck 196264). The Zaitha anura of Champion (1901) is interpreted nowadays as a mixture of species and the Cuban specimens originally seem by him probably corresponds to B. ellipticum Latreille, 1833.

The naucorid Pelocoris poeyi (GuérinMéneville, 1835) was considered a juniorsynonym of $P$. femoratus (Palisot de Beauvois, 1805), until Nieser (1969) revalidated that species. This erroneous synonymy lead to mistaken records of $P$. femoratus from Cuba, as may be seen in Alayo $(1967,1974)$, Aldana \& Fonseca (2001), Puerta (2002), Hernández \& Cala (2003), Hernández \& Bauta (2003), Deler-Hernández et al. (2007) and Alvarez (2007). Finally, Pelocoris convexus Nieser, 1969 was described from the Antilles, but Nieser (1975) synonymized his $P$. convexus with $P$. poeyi.

Biogeographic analysis: Six of the 86 species listed were removed due to lack of information (Table 1). According to Samek's Biogeographic Sectors, Eastern Cuba bears a total of 53 species $(61.63 \%)$, being the most representative sector, whereas Central Cuba is the poorest sector, with only 36 species (41.86\%). Similar results were found for species in one of the sectors. Sixteen species were reported only for the Eastern Sector (18.60\%), $14(16.28 \%)$ are restricted to Western Sector and only six $(6.98 \%)$ occur exclusively in Central Sector (Table 1, Fig. 1). There are only 15 pan-Cuban species (17.44\%), whereas 13 species $(15.12 \%)$ may be found in Eastern and Western Cuba, eight $(9.30 \%)$ in Eastern and Central Cuba, and six $(6.98 \%)$ are distributed in Central and Western Cuba (Fig. 1).

The highest BSI (25\%) was observed between Sectors East-West, whereas EastCenter and West-Center similarities amounted to $16 \%$ and $14 \%$, respectively. The highest value of the East-West sectors may be due to the fact that these areas were targets of more collections in the past, and thus reported the largest number of species. It is possible that intense collections in the Central Sector could change this interpretation.

Finally, it was noted that families represented by few species are restricted to one or two biogeographic sectors, with the exception of Pleidae, which has only one widely distributed species on the island (Table 1).

Distributional preferences: The habitat preference evaluation was based on data from 34 species (Table 2). More than a half of the species analyzed, 20 in total $(58.8 \%)$, prefer stagnant habitats. Only two species $(5.8 \%)$ were restricted to flowing areas, and 12 $(35.4 \%)$ were found in both habitats. The two species collected exclusively in flowing areas are Rhagovelia mira Drake \& Harris, 1938 (Veliidae) and Sigara bradleyi (Abbott, 1913) (Corixidae). Members of the genus Rhagovelia are usually found in fast running rivers, including areas of swift current. Corixids are almost always associated with stagnant waters rich in algae due to their scraping feeding habitat, and the presence of $S$. bradleyi preferably in flowing habitats is probably due to accidental

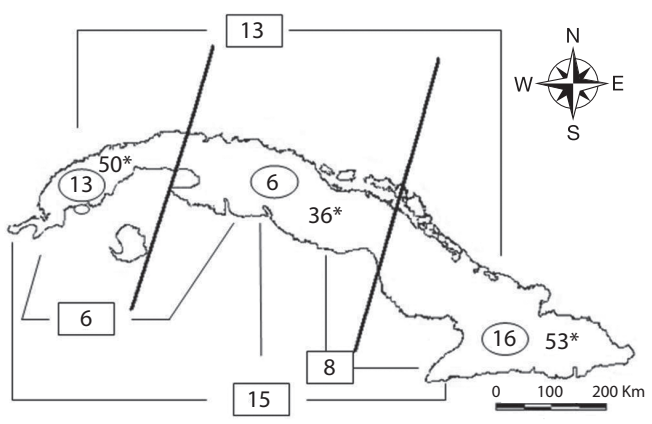

Fig. 1. Geographic distribution of aquatic and semiaquatic Heteroptera in Cuba, following the biogeographical sectors defined by Samek (1973). The two oblique lines separate the Eastern, Central and Western sectors. Numbers with asterisks represent the total of species in each sector. Circled numbers represent the total number of species found in each sector. Numbers in boxes represent the number of species common to a given set of connected sectors. 
TABLE 1

Species and morphospecies surveyed and their geographic distribution

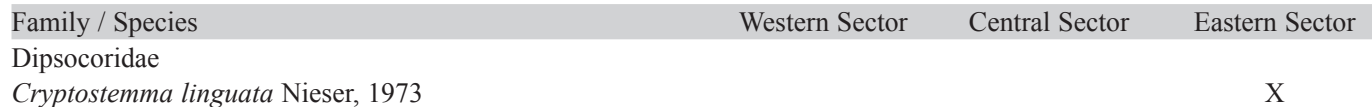

\section{Saldidae}

Micracanthia humilis (Say, 1832)

$\mathrm{X}$

Pentacora hirta (Say, 1832)

Pentacora signoreti (Guérin-Méneville, 1857)

Pentacora sphacelata (Uhler, 1877)

Saldula coxalis (Stål, 1873)

Saldula pallipes (Fabricius, 1803)

Saldidae Gn. Sp1

Saldidae Gn. Sp2

Gerridae

Eurygerris beieri (Drake \& Harris, 1934)

Eurygerris cariniventris (Champion, 1898)

Eurygerris dominicus (Drake \& Maldonado-Capriles, 1956)

Halobates micans Eschscholtz, 1822

Limnogonus franciscanus (Stål, 1859)

Limnogonus recens Drake \& Harris, 1934

Limnogonus sp.

Metrobates tumidus Anderson, 1932

Metrobates sp.

Neogerris hesione (Kirkaldy, 1902)

Rheumatobates clanis Drake \& Harris, 1932

Rheumatobates meinerti Schroeder, 1931

Rheumatobates vegatus Drake \& Harris, 1942

Rheumatobates sp.

Trepobates carri Kittle, 1982

Trepobates pictus (Herrich-Schäffer, 1848)

Trepobates taylori (Kirkaldy, 1899)

Trepobates sp.

Hebridae

Hebrus concinnus Uhler, 1894

Hebrus consolidus Uhler, 1894

Merragata hebroides White, 1877

Hermatobatidae

Hermatobates bredini Herring, 1965

Hydrometridae

Hydrometra australis Say, 1832

Hydrometra caraiba Guérin-Méneville, 1857

Hydrometra consimilis Barber, 1923

Hydrometra gibara Torre-Bueno, 1926

Hydrometra sp.

Mesoveliidae

Mesovelia amoena Uhler, 1894

Mesovelia mulsanti White, 1879

Veliidae

Microvelia albonotata Champion, 1898

Microvelia cubana Drake, 1951

Microvelia longipes Uhler, 1894

Microvelia mimula White, 1879

Microvelia paludicola Champion, 1898

Microvelia pulchella Westwood, 1834
X

X

X

*

$\mathrm{X}$

$\mathrm{X}$

X

X

X X

X

X

X

X

X

X

X

X

X

X

X

X

X

X

X

X

X

$*$

$\mathrm{X}$

X

X

*

X

X

X

X

X

X

X

X

$\mathrm{X}$

$X$
$X$

X

X

X 
TABLE 1 (Continued)

Species and morphospecies surveyed and their geographic distribution

Family / Species

Microvelia sp.

Platyvelia brachialis (Stål, 1860)

Rhagovelia collaris (Burmeister, 1835)

Rhagovelia cubana Polhemus, 1997

Rhagovelia mira Drake \& Harris, 1938

Rhagovelia plumbea Uhler, 1894

Steinovelia stagnalis (Burmeister, 1835)

Belostomatidae

Belostoma ellipticum Latreille, 1833

Belostoma minor (Palisot de Beauvois, 1805)

Benacus griseus (Say, 1832)

Lethocerus colossicus (Stål, 1854)

Lethocerus medius (Guérin-Méneville, 1857)

Corixidae

Centrocorisa nigripennis (Fabricius, 1803)

Corisella edulis (Champion, 1901)

Ramphocorixa rotundocephala Hungerford, 1927

Sigara bradleyi (Abbott, 1913)

Sigara cubiensis Hungerford, 1948

Sigara jarmanae Hungerford, 1939

Trichocorixa louisianae Jaczewski, 1931

Trichocorixa minima (Abbott, 1913)

Trichocorixa sexcinta (Champion, 1901)

Trichocorixa reticulata (Guérin-Méneville, 1857)

Trichocorixa verticalis (Fieber, 1851)

Trichocorixa sp.

Gelastocoridae

Gelastocoris oculatus oculatus (Fabricius, 1798)

Gelastocoris oculatus variegatus (Guérin-Méneville, 1844)

Naucoridae

Pelocoris poeyi (Guérin-Méneville, 1835)

Nepidae

Ranatra fabricii Guérin-Méneville, 1857

Ranatra sagrai Drake \& De Carlo, 1953

Notonectidae

Buenoa antigone (Kirkaldy, 1899)

Buenoa albida (Champion, 1901)

Buenoa gracilis Truxal, 1953

Buenoa macrophtalma (Fieber, 1851)

Buenoa pallipes (Fabricius, 1803)

Buenoa platycnemis (Fieber, 1851)

Buenoa scimitra Bare, 1925

Buenoa sp.

Notonecta indica Linnaeus, 1771

Notonecta confusa Hungerford, 1930

Ochteridae

Ochterus acutangulus (Champion, 1901)

Ochterus hungerfordi Schell, 1943

Pleidae

Paraplea puella (Barber, 1923)
Western Sector Central Sector

Eastern Sector

X

X

X

X

X

X

X

X

X

X

X

X

X

X

X

X

X

$\mathrm{X}$

$\mathrm{X}$

$\mathrm{X}$

X

X

X

X

X

X

X

$\mathrm{X}$

X

X

X

X

X

X

X

X

X

$\mathrm{X}$

X

$\mathrm{X}$

$\mathrm{X}$

X

X

X

$\mathrm{X}$

$\mathrm{X} \quad \mathrm{X}$

X $\quad$ X

X

X

$\mathrm{X}$
$*$

X

X

X

X

X X

X X

$\mathrm{X} \quad \mathrm{X}$

$\mathrm{X}$

X

*

$\mathrm{X}$

X

* $\quad * \quad$ *

$\mathrm{X}$

$\mathrm{X}$

X

X

X

* - no data available. 
TABLE 2

Distribution of the species recorded in relation to habitat, season and altitude

\begin{tabular}{|c|c|c|c|c|c|c|c|c|}
\hline \multirow{2}{*}{ Species } & \multicolumn{2}{|c|}{ Habitat } & \multicolumn{2}{|c|}{ Season } & \multicolumn{4}{|c|}{ Altitudinal Groups } \\
\hline & Flowing & Stagnant & Dry & Rainy & A & $\mathrm{B}$ & $\mathrm{C}$ & $\mathrm{D}$ \\
\hline Saldula pallipes (Fabricius, 1803) & $*$ & * & $\mathrm{X}$ & $\mathrm{X}$ & & $\mathrm{X}$ & & \\
\hline Saldidae Gn. Sp1 & $*$ & $*$ & $\mathrm{X}$ & $\mathrm{X}$ & & $\mathrm{X}$ & & \\
\hline Saldidae Gn. Sp2 & $*$ & $*$ & $\mathrm{X}$ & - & $\mathrm{X}$ & & & \\
\hline Eurygerris cariniventris (Champion, 1898) & $*$ & $*$ & $*$ & $*$ & & & & $\mathrm{X}$ \\
\hline $\begin{array}{l}\text { Eurygerris dominicus (Drake \& Maldonado- } \\
\text { Capriles, 1956) }\end{array}$ & $X$ & $\mathrm{X}$ & * & $*$ & $*$ & $*$ & $*$ & $*$ \\
\hline Limnogonus franciscanus (Stål, 1859) & - & $\mathrm{X}$ & $\mathrm{X}$ & $\mathrm{X}$ & & & $\mathrm{X}$ & \\
\hline Limnogonus sp. & * & * & $\mathrm{X}$ & $\mathrm{X}$ & & $\mathrm{X}$ & & \\
\hline Metrobates tumidus Anderson, 1932 & - & $\mathrm{X}$ & $\mathrm{X}$ & $\mathrm{X}$ & & & & $\mathrm{X}$ \\
\hline Metrobates sp. & * & * & $\mathrm{X}$ & - & $*$ & $*$ & * & $*$ \\
\hline Neogerris hesione (Kirkaldy, 1902) & $\mathrm{X}$ & $\mathrm{X}$ & $\mathrm{X}$ & $\mathrm{X}$ & $*$ & $*$ & $*$ & $*$ \\
\hline Rheumatobates meinerti Schroeder, 1931 & - & $\mathrm{X}$ & $*$ & $*$ & $*$ & $*$ & $*$ & * \\
\hline Rheumatobates vegatus Drake \& Harris, 1942 & $\mathrm{X}$ & $\mathrm{X}$ & - & $\mathrm{X}$ & $\mathrm{X}$ & & & \\
\hline Rheumatobates sp. & - & $\mathrm{X}$ & $\mathrm{X}$ & - & $\mathrm{X}$ & & & \\
\hline Trepobates carri Kittle, 1982 & $\mathrm{X}$ & $\mathrm{X}$ & $\mathrm{X}$ & $\mathrm{X}$ & $*$ & $*$ & $*$ & $*$ \\
\hline Trepobates pictus (Herrich-Schäffer, 1848) & $\mathrm{X}$ & $\mathrm{X}$ & $*$ & * & $*$ & $*$ & $*$ & * \\
\hline Trepobates taylori (Kirkaldy, 1899) & $\mathrm{X}$ & $\mathrm{X}$ & $\mathrm{X}$ & $\mathrm{X}$ & & & $\mathrm{X}$ & \\
\hline Trepobates sp. & * & * & $\mathrm{X}$ & $\mathrm{X}$ & $\mathrm{X}$ & & & \\
\hline Hebrus concinnus Uhler, 1894 & * & * & $\mathrm{X}$ & $\mathrm{X}$ & $*$ & $*$ & $*$ & $*$ \\
\hline Hebrus consolidus Uhler, 1894 & - & $\mathrm{X}$ & $\mathrm{X}$ & $\mathrm{X}$ & $*$ & $*$ & $*$ & $*$ \\
\hline Merragata hebroides White, 1877 & - & $\mathrm{X}$ & $\mathrm{X}$ & $\mathrm{X}$ & & $\mathrm{X}$ & & \\
\hline Hydrometra australis Say, 1832 & - & $\mathrm{X}$ & $*$ & $*$ & $*$ & $*$ & $*$ & $*$ \\
\hline Hydrometra caraiba Guérin-Méneville, 1857 & $*$ & $*$ & $\mathrm{X}$ & $\mathrm{X}$ & & $\mathrm{X}$ & & \\
\hline Hydrometra consimilis Barber, 1923 & * & $*$ & $\mathrm{X}$ & - & $*$ & $*$ & $*$ & * \\
\hline Hydrometra gibara Torre-Bueno, 1926 & $\mathrm{X}$ & $\mathrm{X}$ & - & $\mathrm{X}$ & & $\mathrm{X}$ & & \\
\hline Hydrometra sp. & - & $\mathrm{X}$ & $*$ & $*$ & $*$ & $*$ & $*$ & $*$ \\
\hline Mesovelia amoena Uhler, 1894 & * & * & $\mathrm{X}$ & - & $*$ & $*$ & $*$ & * \\
\hline Mesovelia mulsanti White, 1879 & * & * & $\mathrm{X}$ & $\mathrm{X}$ & & & $\mathrm{X}$ & \\
\hline Microvelia albonotata Champion, 1898 & * & $*$ & $*$ & * & & & & $\mathrm{X}$ \\
\hline Microvelia cubana Drake, 1951 & - & $\mathrm{X}$ & $\mathrm{X}$ & $\mathrm{X}$ & & & & $\mathrm{X}$ \\
\hline Microvelia paludicola Champion, 1898 & $\mathrm{X}$ & $X$ & $\mathrm{X}$ & $\mathrm{X}$ & $\mathrm{X}$ & & & \\
\hline Microvelia pulchella Westwood, 1834 & - & $\mathrm{X}$ & $\mathrm{X}$ & - & $*$ & $*$ & $*$ & * \\
\hline Microvelia sp. & $*$ & $*$ & - & $\mathrm{X}$ & & & $\mathrm{X}$ & \\
\hline Rhagovelia collaris (Burmeister, 1835) & - & $\mathrm{X}$ & $\mathrm{X}$ & $\mathrm{X}$ & & & & $\mathrm{X}$ \\
\hline Rhagovelia cubana Polhemus, 1997 & $*$ & $*$ & $\mathrm{X}$ & $\mathrm{X}$ & & & & $\mathrm{X}$ \\
\hline Rhagovelia mira Drake \& Harris, 1938 & $\mathrm{X}$ & - & - & $\mathrm{X}$ & & & & $\mathrm{X}$ \\
\hline Rhagovelia plumbea Uhler, 1894 & - & $X$ & $\mathrm{X}$ & $\mathrm{X}$ & $\mathrm{X}$ & & & \\
\hline Steinovelia stagnalis (Burmeister, 1835) & $*$ & $*$ & $\mathrm{X}$ & $\mathrm{X}$ & $\mathrm{X}$ & & & \\
\hline Belostoma minor (Palisot de Beauvois, 1805) & - & $\mathrm{X}$ & $\mathrm{X}$ & $\mathrm{X}$ & & & $\mathrm{X}$ & \\
\hline Benacus griseus (Say, 1832) & * & $*$ & $\mathrm{X}$ & - & $*$ & $*$ & $*$ & $*$ \\
\hline Lethocerus colossicus (Stål, 1854) & * & $*$ & $\mathrm{X}$ & $\mathrm{X}$ & & & $\mathrm{X}$ & \\
\hline Lethocerus medius (Guérin-Méneville, 1857) & $\mathrm{X}$ & $\mathrm{X}$ & $\mathrm{X}$ & $\mathrm{X}$ & $*$ & * & $*$ & * \\
\hline Ramphocorixa rotundocephala Hungerford, 1927 & - & $\mathrm{X}$ & $\mathrm{X}$ & $\mathrm{X}$ & $*$ & * & * & * \\
\hline Sigara bradleyi (Abbott, 1913) & $\mathrm{X}$ & - & * & * & $\mathrm{X}$ & & & \\
\hline Trichocorixa louisianae Jaczewski, 1931 & * & $*$ & $\mathrm{X}$ & $\mathrm{X}$ & $*$ & $*$ & $*$ & $*$ \\
\hline
\end{tabular}


TABLE 2 (Continued)

Distribution of the species recorded in relation to habitat, season and altitude

\begin{tabular}{|c|c|c|c|c|c|c|c|c|}
\hline \multirow{2}{*}{ Species } & \multicolumn{2}{|c|}{ Habitat } & \multicolumn{2}{|c|}{ Season } & \multicolumn{4}{|c|}{ Altitudinal Groups } \\
\hline & Flowing & Stagnant & Dry & Rainy & A & $\mathrm{B}$ & $\mathrm{C}$ & $\mathrm{D}$ \\
\hline Trichocorixa minima (Abbott, 1913) & - & $\mathrm{X}$ & * & * & $*$ & $*$ & $*$ & $*$ \\
\hline Trichocorixa sexcinta (Champion, 1901) & - & $\mathrm{X}$ & * & $*$ & $*$ & $*$ & $*$ & $*$ \\
\hline Trichocorixa reticulata (Guérin-Méneville, 1857) & $*$ & * & $\mathrm{X}$ & - & $\mathrm{X}$ & & & \\
\hline Trichocorixa sp. & - & $\mathrm{X}$ & $\mathrm{X}$ & $\mathrm{X}$ & & & $\mathrm{X}$ & \\
\hline Gelastocoris oculatus oculatus (Fabricius, 1798) & - & $\mathrm{X}$ & $*$ & $*$ & $*$ & $*$ & $*$ & * \\
\hline $\begin{array}{l}\text { Gelastocoris oculatus variegatus (Guérin- } \\
\text { Méneville, 1857) }\end{array}$ & $\mathrm{X}$ & $\mathrm{X}$ & * & $*$ & & & & $\mathrm{X}$ \\
\hline Pelocoris poeyi (Guérin-Méneville, 1835) & $*$ & * & $\mathrm{X}$ & $\mathrm{X}$ & & $\mathrm{X}$ & & \\
\hline Ranatra fabricii Guérin-Méneville, 1857 & $\mathrm{X}$ & $\mathrm{X}$ & $\mathrm{X}$ & $\mathrm{X}$ & & $\mathrm{X}$ & & \\
\hline Ranatra sagrai Drake \& De Carlo, 1953 & $\mathrm{X}$ & $\mathrm{X}$ & - & $\mathrm{X}$ & $\mathrm{X}$ & & & \\
\hline Buenoa antigone (Kirkaldy, 1899) & $*$ & * & $*$ & $*$ & & & & $\mathrm{X}$ \\
\hline Buenoa gracilis Truxal, 1953 & $*$ & * & $\mathrm{X}$ & - & & & $\mathrm{X}$ & \\
\hline Buenoa macrophtalma (Fieber, 1851) & - & $\mathrm{X}$ & $\mathrm{X}$ & $\mathrm{X}$ & & & & $\mathrm{X}$ \\
\hline Buenoa platycnemis (Fieber, 1851) & * & * & * & $*$ & & & & $\mathrm{X}$ \\
\hline Buеnoa sp. & * & * & - & $\mathrm{X}$ & $*$ & $*$ & $*$ & * \\
\hline Notonecta indica Linnaeus, 1771 & * & * & $\mathrm{X}$ & $\mathrm{X}$ & & & $\mathrm{X}$ & \\
\hline Paraplea puella (Barber, 1923) & - & $\mathrm{X}$ & $\mathrm{X}$ & $\mathrm{X}$ & & $\mathrm{X}$ & & \\
\hline
\end{tabular}

collection or mislabeling. At family level, Hebridae, Notonectidae and Pleidae occurred exclusively on stagnant water, and all other families were represented in both flowing and stagnant habitats (but see note on Corixidae above).

Based on data available from 46 taxa, 31 species $(67.4 \%)$ were found in both seasons, $6(13 \%)$ only during rainy season, and 9 $(19.6 \%)$ were collected only during dry season (Table 2).

Altitudinal distribution of Cuban aquatic bugs was inferred from data available for 39 species (Table 2). Group A (found up to $60 \mathrm{~m}$ asl) was represented by 10 species $(25.6 \%)$, Group B (found up to $200 \mathrm{~m}$ asl) 9 species (23\%), Group C (found up to $600 \mathrm{~m}$ asl) 9 species $(23 \%$ ) and Group D (found up to $750 \mathrm{~m}$ asl) 11 species (28\%). Almost half of the species studied are restricted to altitudes up to $200 \mathrm{~m}$ above sea level. Saldidae, Hebridae, Hydrometridae, Naucoridae, Nepidae and Pleidae were found exclusively on altitudinal groups $\mathrm{A}$ and $\mathrm{B}$, showing that most water bugs exhibit a distinct preference for lower altitudes. Considering species found at higher altitudes (Group D), there is a clear dominance of Veliidae, Gerridae and Notonectidae species, although Gelastocoridae and Belostomatidae are also represented. Gerridae and Veliidae exhibited the most diverse altitudinal preferences, with some species restricted to lower areas, such as Rheumatobates spp. and Steinovelia stagnalis (Burmeister, 1835), and others being more widely distributed, as most members of the genus Rhagovelia.

\section{DISCUSSION}

For the biogeographic analysis, our results are similar to those obtained by Naranjo \& Cañizares (1999), Trapero \& Naranjo (2003), and Naranjo \& González (2005) in their respective studies on the orders Ephemeroptera, 
Odonata and Trichoptera from Cuba. Distributional patterns of these orders and that described here for Heteroptera are consistent with the fact that the main flow of species between Cuba and the American Continent took place through two fundamental means: (1) from North America and Yucatán throughout the Western part of Cuba and (2) from South America throughout the Lesser Antilles arriving in the Eastern part of Cuba. This hypothesis explains the existence of a greater number of species in Eastern and Western Sectors in comparison to Central Sector (Iturralde-Vinent 2004). Notwithstanding that, the greatest number of species on Eastern Cuba is probably related with the presence of the largest number of hydrographic basins, and large well-preserved mountainous ecosystems in this sector.

Our results at the species and family level are similar to those found by Alayo (1967, 1974), and corroborate the preference of aquatic bugs for slow current or stagnant waters. The vast majority of species presented a wide seasonal distribution, whereas only few were restricted to just one season. Saulich \& Musolin (2007) stated that in regions where environmental conditions are constantly stable and favorable, some heteropterans may breed all year round, thus having a homodynamic type of seasonal development. In fact, this might be the case of most Cuban species.

\section{ACKNOWLEDGMENTS}

This manuscript benefited from the useful comments of Viviani P. Alecrim, Ana Lúcia Henriques Oliveira, Renner Luiz Cerqueira Baptista and Carl W. Schaefer. Part of this work was possible thanks to a grant awarded by The Smithsonian Institution at The National Museum of Natural History in Washington D.C.

\section{RESUMEN}

Heteroptera es un grupo de insectos que se distribuyen en todo el mundo, viven en ambientes terrestres $\mathrm{y}$ acuáticos, en los que tienen un papel ecológico muy importante. Mediante la literatura y colecciones en el campo se estudiaron los Heterópteros acuáticos y semiacuáticos de Cuba, junto con datos sobre la distribución geográfica de las especies, altitud y estaciones de colecta. Se enumeran representantes de 86 especies y morfospecies de los infraórdenes Dipsocoromorpha, Leptopodomorpha, Gerromorpha y Nepomorpha, con un total de 35 géneros y 16 familias. Los datos de distribución muestran una preferencia por los ambientes de aguas lentas o estancadas y áreas de baja altitud. Quince especies se distribuyen en toda la isla; el sector Oriental es el mejor representado, con 53 especies (61.63\%), 16 de ellas $(18.60 \%)$ confinadas a este sector. La similitud biológica más fuerte se encontró entre los sectores oriental y occidental (25\%) y la más débil entre los sectores occidental y central (14\%).

Palabras clave: chinches acuáticos, biogeografía, lista de especies, Región Neotropical.

\section{REFERENCES}

Alayo, P. 1967. Catálogo de la fauna de Cuba. 16. Los hemípteros acuáticos de Cuba. Museo Felipe Poey, Academia de Ciencias de Cuba, Trabajos de Divulgación 38: 1-68.

Alayo, P. 1971. Los hemípteros acuáticos de Cuba. Adiciones y enmiendas. Museo Felipe Poey, Academia de Ciencias de Cuba, Trabajos de Divulgación 63: 1-17.

Alayo, P. 1974. Los hemípteros acuáticos de Cuba. Torreia (nueva serie) 36: 9-64.

Aldana, M. \& L. Fonseca. 2001. Caracterización ecológica de la macrofauna del Río Mayarí. Monograph, Universidad de Oriente, Santiago de Cuba, Cuba.

Alvarez, G. 2007. Caracterización de la macrofauna de invertebrados y análisis de la calidad del agua del Río Guantánamo: Provincia Guantánamo. Monograph, Universidad de Oriente, Santiago de Cuba, Cuba.

Andersen, N.M. 1975. The Limnogonus and Neogerris of the Old World with character analysis and a reclassification of the Gerrinae (Hemiptera: Gerridae). Entomol. Scand. (supplementa) 7: 7-96.

Andersen, N.M. 1982. The semiaquatic bugs (Heteroptera: Gerromorpha). Phylogeny, adaptations, biogeography and classification. Entomonograph 3: 1-455.

Anderson, L.D. 1932. A monograph of the genus Metrobates (Hemiptera, Gerridae). Univ. Kans. Sci. Bull. 20: 297-311.

Bello, O. 2004. Caracterización ecológica de la macrofauna del Río Máximo. Monograph, Universidad de Oriente, Santiago de Cuba, Cuba. 
Champion, G.C. 1901. Hemiptera-Heteroptera. Biologia Centrali-Americana, Rhynchota 2: 1-416.

Deler-Hernández, A., Y.S. Megna, D.D. González-Lazo \& C.N. Cracasés-Torres. 2007. Insectos acuáticos y áreas prioritarias para la conservación en la cuenca alta del Río Cauto (Santiago de Cuba, Cuba). Bol. Entomol. Aragonesa 40: 451-451.

Drake, C.J. 1938. A new Rhagovelia from Cuba. Pan-Pac. Entomol. 14: 152.

Drake, C.J. 1952. Concerning American Ochteridae (Hemiptera). Fla. Entomol. 35: 72-75.

Drake, C.J. \& J.A. De Carlo. 1953. American species of Ranatra annulipes Stål group (Hemiptera: Ranatridae). J. Wash. Acad. Sci. 43: 109-117.

Drake, C.J. \& H.M. Harris. 1942. Notas sobre Rheumatobates, com descrição de uma nova espécies (Hemiptera, Gerridae). Rev. Bras. Biol. 2: 399-402.

Drake, C.J. \& H.M. Harris. 1943. Notas sobre Hebridae del Hemisferio Occidental (Hemiptera). Notas del Museo de La Plata. Zoología 8: 41-58.

Drake, C.J. \& R.F. Hussey. 1955. Concerning the genus Microvelia Westwood, with descriptions of two new species and a check-list of American forms (Hemiptera: Veliidae). Fla. Entomol. 38: 95-115.

Drake, C.J \& P.H. Van Doesburg. 1966. Water-striders of the American genus Trochopus (Hemiptera: Veliidae). Stud. Fauna Suriname Guyanas 8: 65-76.

Feinsinger, P. 2004. El diseño de estudios de campo para la conservación de la biodiversidad. FAN, Santa Cruz de La Sierra, Bolivia.

Guérin-Méneville, F.E. 1857. Ordre des Hémiptères, Latr. Premiere section. Hétéroptères Latr., p. 359-424. In R. de la Sagra (ed.). Histoire physique, politique et naturelle de l'Ile de Cuba. Arthur Bertrand, Paris, France.

Hernández, D. \& Y. Bauta. 2003. Caracterización de la macrofauna dulceacuícola de los Ríos Gibara y Cacoyugüin (Holguín). Monograph, Universidad de Oriente, Santiago de Cuba, Cuba.

Hernández, D. \& Y. Cala. 2003. Macrofauna dulceacuícola de invertebrados y la calidad de las aguas del Río Sevilla, Municipio Niquero (Granma). Monograph, Universidad de Oriente, Santiago de Cuba, Cuba.

Hungerford, H.B. 1933. The genus Notonecta of the World (Notonectidae-Hemiptera). Univ. Kans. Sci. Bull. 21: 5-195.
Hungerford, H.B. 1948. The Corixidae of the Western Hemisphere (Hemiptera). Univ. Kans. Sci. Bull. 32: 5-827.

Hungerford, H.B. 1954. The genus Rheumatobates Bergroth (Hemiptera-Gerridae). Univ. Kans. Sci. Bull. 36: 529-588.

Hungerford, H.B. \& N.E. Evans. 1934. The Hydrometridae of the Hungarian National Museum and other studies on the family (Hemiptera). Ann. Mus. Natl. Hungarici 28: 32-112.

Iturralde-Vinent, M. 2004. Origen y evolución del Caribe y sus biotas marinas y terrestres. Centro Nacional de Información Geológica, La Habana, Cuba.

Jenkins, D.W. 1964. Pathogens, parasites and predators of medically important Arthropods, annotated list and bibliography. B. World Health Organ. (supplement): $1-150$.

Kirkaldy, G.W. \& J.R. de la Torre-Bueno. 1909. A catalogue of American aquatic and semiaquatic Hemiptera. Proc. Entomol. Soc. Wash. 10: 173-213.

Kittle, P.D. 1982. Two new species of water striders of the genus Trepobates Uhler (Hemiptera: Gerridae). Proc. Entomol. Soc. Wash. 84: 157-164.

Kuitert, L.C. 1942. Gerrinae in University of Kansas Collections. Univ. Kans. Sci. Bull. 28: 113-143.

Lauck, D.L. 1959. Three new species of Belostoma from Mexico and Central America (Hemiptera: Belostomatidae), with a list of North American species. B. Chic. Aca. Sci. 11: 1-9.

Lauck, D. L. 1962-64. A monograph of the genus Belostoma. Parts I-III. B. Chic. Aca. Sci. 11: 34-154.

Martin, C.H. 1928. An exploratory survey of the characters of specific value in the genus Gelastocoris Kirkaldy, and some new species. Univ. Kans. Sci. Bull. 18: 351-359.

Menke, A.S. 1963. A review of the American genus Lethocerus in North and Central America, including the West Indies. Ann. Entomol. Soc. Am. 56: 261-267.

Menke, A.S. 1979. The semiaquatic and aquatic Hemiptera of California (Heteroptera: Hemiptera). Bull. Calif. Insect Surv. 21: 1-166.

Naranjo, C. \& M. Cañizares. 1999. Situación actual del estudio del orden Ephemeroptera en Cuba (Insecta). Cocuyo 8: 17-19. 
Naranjo, C. \& D. González. 2005. Situación actual del estudio del orden Trichoptera en Cuba. Bol. Soc. Entomol. Aragonesa 36: 147-152.

Nieser, N. 1969. The Heteroptera of the Netherlands Antilles - VIII. Pleidae, Naucoridae, Ranatridae. Stud. Fauna Curaçao Caribb. Isl. 30: 58-71.

Nieser, N. 1973. Semiaquatic Heteroptera from Cuba Résultats des Expéditions Biospéleologiques Cubano-Roumaines à Cuba 1: 347-350.

Nieser, N. 1975. The water bugs (Heteroptera: Nepomorpha) of the Guyana Region. Stud. Fauna Suriname Guyanas 59: 1-303.

Nieser, N. 1977. Aquatic and semiaquatic Heteroptera from Cuba. Résultats des Expéditions Biospéleologiques Cubano-Roumaines à Cuba 2: 355-360.

Nieser, N. \& A.L. Melo. 1997. Os Heterópteros aquáticos de Minas Gerais. Guia introdutório com chave de identificação para as espécies de Nepomorpha e Gerromorpha. Editora UFMG, Belo Horizonte, Brazil.

Perez-Goodwyn, P.J. 2006. Taxonomic revision of the subfamily Lethocerinae Lauck \& Menke (Heteroptera: Belostomatidae). Stuttgarter Beiträge zur Naturkunde, serie A (Biologie) 695: 1-71.

Polhemus, D.A. 1997. Systematics of the genus Rhagovelia (Heteroptera: Veliidae) in the Western Hemisphere (exclusive of the angustipes complex). Thomas Say Monographs in Entomology, Entomological Society of America, Lanham, Maryland, USA.

Polhemus, J.T. \& J.L. Herring. 1979. A further description of Hermatobates bredini Herring, and a new record for Cuba (Hemiptera: Hermatobatidae). Proc. Entomol. Soc. Wash. 81: 253-254.

Polhemus, J.T. \& D.A. Polhemus. 2007. Global trends in the description of aquatic and semiaquatic Heteroptera species, 1758-2004. Tijdschrift voor Entomologie 150: $271-288$.

Polhemus, J.T. \& D.A. Polhemus. 2008. Global diversity of true bugs (Heteroptera; Insecta) in freshwater. Hydrobiologia 595: 379-391.

Puerta, Y. 2002. Caracterización de la macrofauna dulceacuícola del Río Táyaba. Monograph, Universidad de Oriente, Santiago de Cuba, Cuba.

Samek, V. 1973. Regiones fitogeográficas de Cuba. Academia de Ciencias de Cuba, Serie Florestal 15: 1-60.

Saulich A.H. \& D.L. Musolin. 2007. Seasonal development of aquatic and semiaquatic True Bugs (Heteroptera). St. Petersburg University, Saint Petersburg, Russia.

Trapero, A. \& C. Naranjo. 2003. Revision of the order Odonata in Cuba. B. Am. Odonat. 2: 23-40.

Truxal, F.S. 1953. A revision of the genus Buenoa (Hemiptera: Notonectidae). Univ. Kans. Sci. Bull. 35: 1351-1517.

Uhler, P.R. 1893. A list of the Hemiptera-Heteroptera collected in the Island of St. Vincent by Mr. Herbert H. Smith; with descriptions of new genera and species. Proc. Zool. Soc. Lond. 1893: 705-719.

Uhler, P.R. 1894. On the Hemiptera-Heteroptera of the Island of Grenada, West Indies. Proc. Zool. Soc. Lond. 1894: 167-224. 